\title{
0092. Ischemic pre/post-conditioning protects the microcirculation in experimental sepsis
}

\author{
D Orbegozo Cortes ${ }^{*}$, S Fuhong, C Santacruz, K Hosokawa, K Donadello, J Creteur, D De Backer, J-L Vincent \\ From ESICM LIVES 2014 \\ Barcelona, Spain. 27 September - 1 October 2014
}

\section{Introduction}

Ischemic preconditioning induces complex physiological adaptations to improve the tolerance of cells and tissues to future ischemic episodes. This phenomenon has been most studied in myocardial cells but also occurs in other tissues.

\section{Objectives}

Ischemic preconditioning could be used to improve the microcirculatory response to sepsis related hypoperfusion.

\section{Methods}

Sixteen adult sheep (24-34 Kg) were anesthetized (midazolam, ketamine and morphine), mechanically ventilated and invasively monitored. Abdominal sepsis was induced by injecting autologous feces into the peritoneal cavity. Animals were randomly allocated to undergo remote ischemic preconditioning followed by intermittent postconditioning (PRECON) or not (CONTROL). Controlled ischemic episodes of the lower extremities and pelvis were obtained by inflating an intravascular balloon in the aortic bifurcation. We performed 4 cycles of $2 \mathrm{~min}$ ischemia ( 4 min apart) 1 hour before sepsis induction and, thereafter, 1 inflation every 4 hours until death. Sublingual microcirculation was evaluated using sidestream dark field (SDF) video-microscopy capturing 5 videos of $12 \mathrm{sec}$ at baseline and every 6 hours thereafter for later blinded analysis. We calculated the perfused vessel density (PVD), proportion of perfused vessels (PPV), mean flow index (MFI) and heterogeneity of PPV (PPV HI). Animals were followed until death or for a maximum of 30 hours. Data are presented as median values with inter-quartile ranges. Repeated measurement data were analyzed using a Generalized Estimating Equations approach in SPSS 19.0 (IBM,USA) with a p < 0.05 considered as significant.

\section{Results}

See table 1.

Table 1

\begin{tabular}{ccccccc}
\hline & & T0 & T6 & T12 & T18 & T24 \\
\hline PVD (vessel/mm) & PRECON & $13.0(12.8-15.8)$ & $10.6(9.8-12.1)$ & $9.0(8.6-11.1)$ & $9.2(8.5-10.1)$ & $8.2(7.3-9.3)^{*}$ \\
\hline & CONTROL & $13.8(12.5-15.7)$ & $10.4(9.5-11.3)$ & $9.1(8.6-10.8)$ & $7.7(6.9-9.6)$ & $6.2(5.0-6.7)$ \\
\hline PPV (\%) & PRECON & $98(97-99)$ & $91(89-93)^{*}$ & $86(82-93)$ & $84(82-89)^{*}$ & $77(76-83)^{*}$ \\
\hline MFI (0-3) & CONTROL & $97(97-98)$ & $89(86-90)$ & $84(82-87)$ & $77(66-84)$ & $58(50-65)$ \\
\hline PPV HI (\%) & PRECON & $3.0(2.9-3.0)$ & $2.6(2.5-2.7)$ & $2.2(2.1-2.6)$ & $2.3(2.1-2.6)^{*}$ & $2.2(2.1-2.4)^{*}$ \\
\hline & CONTROL & $2.9(2.9-3.0)$ & $2.4(2.3-2.5)$ & $2.2(2.1-2.4)$ & $1.7(1.5-2.1)$ & $1.2(1.0-1.4)$ \\
\hline & PRECON & $3(3-5)$ & $9(5-15)^{*}$ & $16(11-40)$ & $21(18-39)$ & $35(25-39)^{*}$ \\
\hline
\end{tabular}

[Sublingual microcirculatory variables]

$*=p<0.05$ compared with control group. 


\section{Conclusions}

Repeated ischemic pre- and post-conditioning of the pelvis and lower extremities protected the microcirculation in this sheep model of severe abdominal sepsis.

\section{Grant acknowledgment}

Institutional funds only

Published: 26 September 2014

doi:10.1186/2197-425X-2-S1-P4

Cite this article as: Cortes et al.: 0092. Ischemic pre/post-conditioning

protects the microcirculation in experimental sepsis. Intensive Care

Medicine Experimental 2014 2(Suppl 1):P4.

\section{Submit your manuscript to a SpringerOpen ${ }^{\mathcal{O}}$ journal and benefit from:}

- Convenient online submission

- Rigorous peer review

- Immediate publication on acceptance

- Open access: articles freely available online

- High visibility within the field

- Retaining the copyright to your article

Submit your next manuscript at $\gg$ springeropen.com 